tem instead of eyes. With its solar sails it flies around the inner solar system as far as the main belt of asteroids. At any one time there will be hundreds of such birds flying, programmed to make specialized observations of Earth, Moon, Sun, planets, and asteroids as well as the heavens beyond. Other cousins of the Astrochicken will have legs for landing and hopping around on asteroids, or solarpowered ion-jet engines for exploring the outer solar systems as far as Pluto.

Dyson rehearses his provocative notion that the countless comets of the Oort cloud thought to surround the Solar System are fit for human habitation. Comets, he suggests,

provide an open frontier, a place to hide and to disappear without trace, beyond the reach of snooping policemen and bureaucrats.... Near to the Sun, space will belong to big governments and computerized industries. Outside, the open frontier will beckon as it has beckoned before, to persecuted minorities escaping from oppression, to religious fanatics escaping from their neighbors, to recalcitrant teenagers escaping from their parents, to lovers of solitude escaping from crowds.

Coming down to Earth, Dyson offers an analysis of carbon dioxide in the atmosphere that is sufficiently clearheaded and free from bombast to make it recommended reading for all parties in the global-warming debate, whatever their level of expertise: "In this chapter I shall be mainly concerned with facts and figures", he writes, and the facts and figures he provides are enlightening. Earth's atmosphere contains about 7,000 gigatons of carbon. The industrialized world is dumping more than six gigatons of carbon into the atmosphere every year. Deforestation and soil erosion add about another three gigatons annually. That's a total contribution of nine gigatons - yet measurements of the atmosphere show an increase of only half that much. Where is the missing carbon? Not in the oceans: "Oceanic measurements do not support" this interpretation. "So the mystery remains", Dyson notes. $\mathrm{He}$ concludes, not with an easy denunciation of the excesses of the developed world, but with a modest plea for "more observations".

With similar aplomb, Dyson calls for global monitoring of carbon's complement, the oxygen content of the atmosphere. "I am surprised that the general public all over the world is not clamoring to know how fast we are using up the oxygen", he writes. But he adds that it "is not only bureaucrats who are to blame. We scientists are also to blame for not practicing what we preach. It is easy to give advice, and not so easy to follow it." In a footnote he informs us that soon after his essay was published, in 1990, a young Princeton physicist took up the challenge of making continual measurements of global oxygen levels. Were ecologists' contributions to the global-warming debate habitually couched in similarly thoughtful and constructive terms, they might more often see such prompt and palpable results.

Turning his attention to the classroom, Dyson offers the puckish precept that schools might in some cases do better to teach less science and more Greek and Latin - to function, in other words, as (classically) better schools. In an admirably balanced passage, he portrays the edifice of science as a hexagon with three ugly faces - science as "a rigid and authoritarian discipline, tied to mercenary and utilitarian ends, and tainted by its association with weapons of mass murder" - and three beautiful faces - "science as subversion of authority, science as an art form, and science as an international club". "The way to attract young people into science", he writes, "is to show them all six faces and give them freedom to explore the beautiful and the ugly as they please."

Education provides an insight into

Dyson's character. Never content to present himself as an oracle or sage, he seems always to keep learning, and he encourages his colleagues to do the same. At one point he recalls that he

shared an office for a month with a professor of sanitary engineering who taught me about biological oxygen demand and activated sludge. This was great fun, and my office mate was brighter than most of the physicists I know. I would advise any physicists who have a genuine concern for the environment to take the time to find out what the problems are in the field of activated sludge.

Seldom have the more attractive faces of science shone more brilliantly than on the pages of this estimable book. Dyson's writing casts a chalk-white beacon into many an out-of-the-way cranny, and illuminates all that he surveys.

Timothy Ferris is at the Graduate School of Journalism, University of California, Berkeley, California 94720, USA, and is the author of Coming of Age in the Milky Way, The Mind's Sky and other books on astronomy and physics.

\title{
Differing world views
}

\section{E. G. Nisbet}

The Age of the Earth. By G. Brent Dalrymple. Stanford University Press: 1991. Pp. 474. $\$ 49.50$.

The Facts of Life: Shattering the Myth of Dawwinism. By Richard Milton. Fourth Estate: 1992. Pp. 288. £16.99.

KELVIN paid up. The sum was five shillings, and the bet was about the properties of radium. Would radioactivity invalidate his calculations of the age of the Earth? The winner was R. J. Strutt, later to become Lord Rayleigh; the Earth did indeed seem to be much older than Kelvin's estimate based on cooling. In 1904, Rutherford lectured on the topic. He described his apprehension when he spotted Kelvin in the audience; to his relief, Kelvin fell asleep, but as Rutherford came to the critical point, he saw the "old bird" sit up, open an eye and cock a baleful glance. Rutherford escaped by pointing to the heat generated by radioactivity, and the old boy beamed at him.

Since Kelvin's day, it has been unanimously accepted by orthodox scientists that the Earth is old. Radioactive heat was not the only reason Kelvin was wrong: the Earth's interior is convective, not conductive, and is still slowly losing both primaeval and radiogenic heat. The Earth is roughly 4.5 billion $\left(10^{9}\right)$ years old. Although there is still debate about the accuracy and precision of that number, its general magnitude is certain. If the number is very seriously wrong, and the planet is only a few thousand years old, then not only geology but a good chunk of physics, chemistry and applied mathematics is also in error. Rutherford realized the importance of his discoveries. On his Nobel citation (a lovely document -- there is a copy at McGill University) are the classic curves of radioactive decay, and he chose them for his coat of arms. They are central to much of modern physics.

G. Brent Dalrymple is a widely respected geochronologist, and his book is a fine exposition of the enormous body of evidence that shows, unequivocally, that Rutherford was right, the Earth is old. Ironically, we have the creationists to thank for this book, which was written in answer to their onslaught. Dalrymple's scholarly but readable account passes from an opening act on the early debates about the planet's age, to the main argument on the basis of radiometric dating. Once the groundwork is done, the book progresses through a discussion of Earth's oldest rocks and the direct evidence for old crust, to chapters on the supporting cast - the Moon and meteorites and then gets down to the hard action of lead isotopes, followed by a finale on the Universe and all that it contains. Through- 
out the work, the writing is careful, unjournalistic but well written science. Parts of it are not especially easy - lead isotopes in particular are horrendously complex. Putting an exact number on the age of the Earth is difficult Dalrymple favours a best value around 4.54 billion years, but the error is around 0.02 billion years. Rutherford's basic point is firm: the Earth is not thousands but billions of years old.

Richard Milton does not accept this, nor does he accept a lot of the rest of the conventional wisdom of biology and geology. Most authors who attack the fabric of geology are creationists, mostly fundamentalist Christian but some Islamic; Milton, in contrast, is a secular writer who states that he holds no religious belief. His work is a work of journalism, in the British tradition that puts opinion on the front page, giving only one side of the debate and placing the judgement of the writer foremost. Consequently, the book has the opinionloaded theological style of the English 'quality' newspapers (tell it to the cobelievers), not the quiet accuracy of the New York Times. The result is an entertaining but wildly misleading work, more in the ways of F. R. Leavis than T. H. Huxley (no stranger to opinion himself), that wholly misunderstands the basis of stratigraphy. Milton's book dismisses the painstakingly careful logic of radiometric dating in a few pages, in contrast to Dalrymple's thorough discussion of lead isotopes. What the book does say about isotopes, for instance about radiogenic helium, is hilarious or irrelevant, and the book evades the rigour of Dalrymple's evidence by the simple device of ignoring it. At least the fundamentalists, on occasion, attempt to meet geochronology squarely; not so here, as the work leaves out virtually all the facts.

Why then bother to review a book that is so flawed? Although Milton spends many pages attacking the view that the Earth is old, the book's main target is not physics and chemistry but biology. The cover has a picture of a shattered Darwin, and with a passing reference to Marxism, the book attempts to consign Charles to the same dustbin as Karl. Here there is a valid point: "ideological Darwinism has replaced scientific Darwinism in our educational system". The Nazis misused Darwin, and so did the Soviets, and the result was inhumanity on a grand scale. In democratic societies too, the impact of the eugenicists was powerful in the first half of the century, and their ingrained influence remains. Even today, the detestation of the 'inferior' is widespread, for instance in the medical profession's commonly held opinion that 'defective' children should not be born. More generally, Tennyson's view of "Nature red in

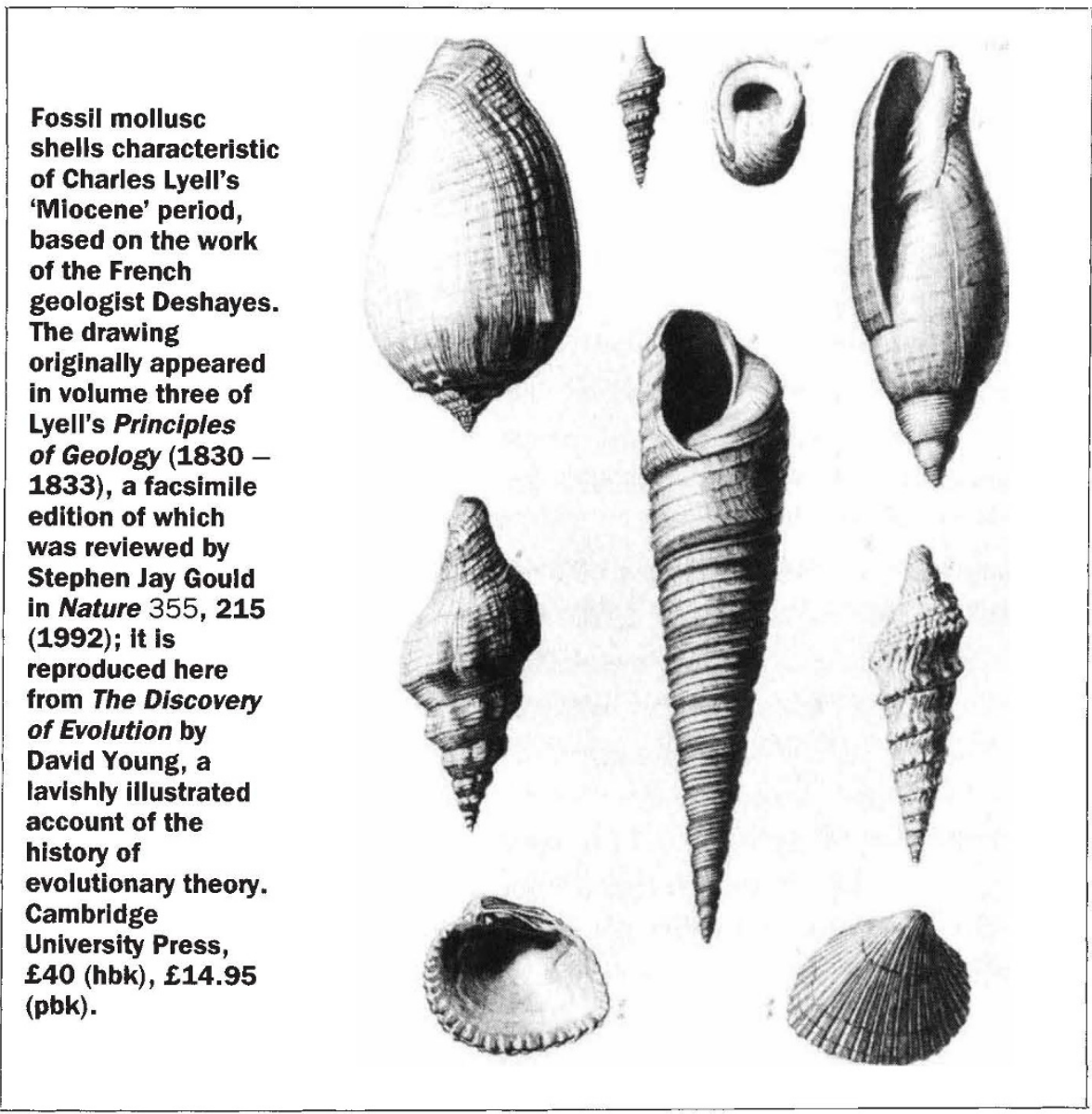

tooth and claw" is used to justify the excesses of $1980 \mathrm{~s}$ capitalism. But are these valid reasons for attacking Darwin himself, who knew none of this?

More vulnerable to attack are some of the great panjandrums of palaeontology. Their discoveries have been enormous, both intellectually and (sometimes) physically (especially the dinosaurs). The best of them are scientists in the classic sense: humble searchers after truth. But publicity and fame often go to the less pure. Among these, the feuds, arrogance and frequent intellectual dishonesty are legendary. One thinks, for instance, of the forger of Piltdown man, of some of the dinosaur discoverers, or of Marie Stopes, whose status as a foundress of palaeobotany and contraception went along with disturbing views on eugenics. But palaeontologists are human too; many have been monuments of integrity, and in their defence is the record that they are their own best critics. As in many things in human history, one should be careful to separate the discovery itself (if true) from the people and motives that led to its uncovering.

Evolution has occurred; the Earth is old; Milton's book is simply wrong. Nevertheless, the book has a point buried deeply in its farrago of misfact. Evolution (especially in bacteria) is a much more subtle process on a molecular level than Darwin could have im- agined, and we should be careful to reflect this in our teaching. Indeed, if we do fall into the trap of comparing human society with nature, then it is the information exchange between bacteria that we should cite, not the record of eukaryote 'survival of the fittest'. There is still much we do not understand about the controls on evolution. Even isotopic systematics have their continuing interest, as hordes of geochemists can testify, and we are still far from understanding the complexities of geochemical cycling.

With luck, someone will read Dalrymple's careful honest work, take note, and be well guided about the truth of Earth history, as far as we can decipher it. The Facts of Life, I fear, will make a greater impression, in misguiding its readers: it is worth recalling the darwinian comment that, while incorrect hypotheses are the life of science, incorrect 'facts' are its death. Nevertheless, we can take refuge in the classical Miltonic view of the Areopagitica that the facts are too strong to be obscured by misinformation. Perhaps if it teaches us some humility, then even a bad book can do a little good.

E. G. Nisbet is in the Department of Geology, Royal Holloway College, University of London, Egham, Surrey TW2O OEX, UK. 